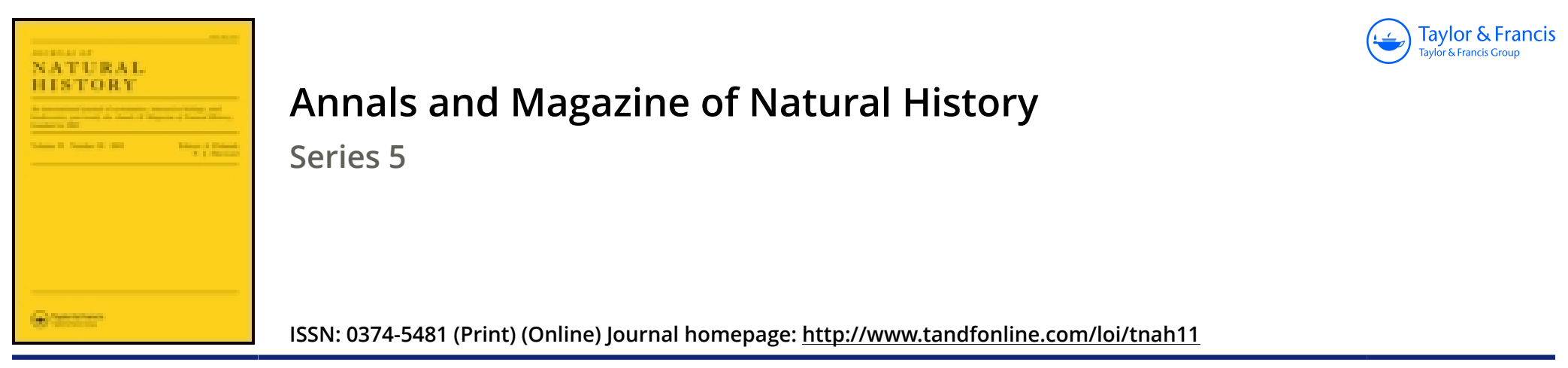

\title{
XLIII._On Palœontological and embryological development
}

\section{Prof. Alexander Agassiz}

To cite this article: Prof. Alexander Agassiz (1880) XLIII._On Palœontological and embryological development , Annals and Magazine of Natural History, 6:35, 348-372, DOI: 10.1080/00222938009458952

To link to this article: http://dx.doi.org/10.1080/00222938009458952

$$
\text { 册 Published online: } 07 \text { Oct } 2009 .
$$

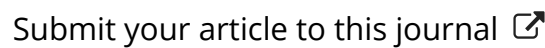

Џ Article views: 3 


\section{XLIII.-On Palocontological and Embryological Development. By Prof. Allexander Agassiz*.}

Since the publication of the 'Poissons Fossiles' by Agassiz, and of the 'Embryologie des Salmonidées' by Vogt, the similarity, traced by the former, between certain stages in the growth of young fishes and the fossil representatives of extinct members of the group has also been observed in nearly every class of the animal kingdom, and the fact has become a most convenient axiom in the study of palæontological and embryological development. This parallelism, which has been on the one side a strong argument in favour of design in the plan of creation, is now, with slight emendations, doing duty on the other as a newly discovered article of faith in the new biology.

But while, in a general way, we accept the truth of the proposition that there is a remarkable parallelism between the embryonic development of a group and its palæontological history, yet no one has attempted to demonstrate this, or, rather, to show how far the parallelism extends. We have, up to the present time, been satisfied with tracing the general coincidence or with striking individual cases.

The resemblance between the pupa stage of some Insects and of adult Crustacea, the earlier existence of the latter, and the subsequent appearance of the former, in palæontological history, furnished one of the first and most natural illustrations of this parallelism; while theoretically the necessary development of the higher tracheate insects from their early branchiate aquatic ancestors seemed to form an additional link in the chain, and point to the Worms, the representatives of the larval condition of Insects, as a still earlier embryonic stage of the Articulates.

Indeed, there is not a single group of the animal kingdom in which embryology has not played a most important part in demonstrating affinities little suspected before. The development of our frogs, our salamanders, has given us the key to much that was unexplained in the history of Reptiles and Batrachians. The little that has been done in the embryology of Birds has revolutionized our ideas of a class which at the beginning of the century seemed to be the most naturally circumscribed of all. Embryology and palæontology combined have led to the recognition of a natural classification

* From 'Science' for September 18, being a verbatim report of the address delivered at the Meeting of the American Association for the Advancement of Science at Boston, August 1880. 
uniting Birds and Reptiles on the one side and Batrachians and Fishes on the other. It is to embryology that we owe the explanation of the affinities of the old Fishes in which Agassiz first recognized the similarity to the embryo of Fishes now living, and by its aid we may hope to understand the relationship of the oldest representatives of the class. It has given us the only explanation of the early appearance of the Cartilaginous Fishes, and of the probable formation of the earliest vertebrate limb from the lateral embryonic fold, still to be traced in the young of the Osseous Fishes of to-day.

Embryology has helped us to understand the changes aquatic animals must gradually undergo in order to become capable of living upon dry land. It has given us pictures of swimming-bladders existing as rudimentary lungs in Fishes with a branchial system; in Batrachians it has shown us the persistence of a branchial system side by side with a veritable lung. We find among the earliest terrestrial Vertebrates types having manifest: affinities with the Fishes on one side and Batrachians on the other, and we call these types Reptiles; but we should nevertheless do so with a reservation, looking to embryology for the true meaning of these half-fledged Reptiles, which lived at the period of transition between an aquatic and terrestrial life, and must therefore always retain an unusual importance in the study of the development of animal life.

When we come to the embryology of the marine Invertebrates, the history of the development of the barnacles is too familiar to be dwelt upon; and I need only allude to the well-known transformations of the Echinoderms, of the Acalephs, Polyps, in fact of every single class of Invertebrates, and perhaps in none more than in the Brachiopods, to show how far-reaching has been the influence of embryology in guiding us to a correct reading of the relations between the fossils of successive formations. There is scarcely an embryological monograph now published dealing with any of the later stages of growth which does not speak of their resemblance to some type of the group long ago extinet. It has therefore been most natural to combine with the attempts constantly made to establish the genetic sequence between the genera of successive formations an effort to establish also a correspondence between their palæontological sequence and that of the embryonic stages of development of the same, thus extending the mere similarity first observed between certain stages to a far broader generalization.

It would carry me too far to sketch out, except in a most 
general way, even for a single class, the agreement known to exist in certain groups between their embryonic development and their palæontological history. It is hinted at in the succession of animal life of any period we may take up, and perhaps cannot be better expressed than by comparing the fauna of any period as a whole with that of following epochs-a zoological system of the Jura, for instance, compared with one made up for the Cretaceous; next, one for the Tertiary compared with the fauna of the present day. In no case could we find any class of the animal kingdom bearing the same definitions or characterized in the same manner. But apply to this comparison the data obtained from the embryological development of our present fauna, and what a flood of light is thrown upon the meaning of the succession of these apparently disconnected animal kingdoms, belonging to different geological periods, especially in connexion with the study of the few ancient types which have survived to the present day from the earliest times in the history of our earth!

Although there is hardly a class of the animal kingdom in which some most interesting parallelism could not be drawn, and while the material for an examination of this parallelism is partially available for the Fishes, Mollusks, Crustacea, Corals, and Crinoids, yet for the illustration and critical examination of this parallelism I have been led to choose to-day a very limited group, that of Sea-urchins, both on account of the nature of the material, and of my own familiarity with their development and with the living and extinct species of Echini. The number of living species is not very great (less than three hundred), and the number of fossil species thus far known is not, according to Zittel, more than about two thousand. It is therefore possible for a specialist to know of his own knowledge the greater part of the species of the group. It has been my good fortune to examine all but a few of the species now known to exist, and the collections to which I have had access contain representatives of the majority of the fossil species. Sea-urchins are found in the oldest fossiliferous rocks; they have continued to exist without interruption in all the strata up to the present time. While it is true that our knowledge of the Sea-urchins occurring before the Jurassic period is not very satisfactory, it is yet complete enough for the purposes of the present essay, as it will enable me, starting from the Jurassic period, to call your attention to the palæontological history of the group, and to compare the succession of its members with the embryological development of the types now living in our 
seas. Ample material for making this comparison is fortunately at hand; it is material of a peculiar kind, not easily obtained, and which thus far has not greatly attracted the attention of zoologists.

Interesting and important as are the earliest stages of embryonic development in the different classes of the animal kingdom, as bearing upon the history of the first appearance of any organ and its subsequent modifications, they throw but little light on the subject before us. What we need for our comparisons are the various stages of growth through which the young Sea-urchins of different families pass, from the time they have practically become Sea-urchins until they have attained the stage which we now dignify with the name of species. Few embryologists have carried their investigations into the more extended field of the changes the embryo undergoes when it begins to be recognized as belonging to a special class, and when the knowledge of the specialist is absolutely needed to trace the bearing of the changes undergone and to understand their full meaning. Fortunately the growth of the young Echini has been traced in a sufficient number of families to enable me to draw the parallelism between these various stages of growth and the palxontological stages in a very different manner from what is possible in other groups of the animal kingdom, where we are overwhelmed with the number of species, as in the Insects or Mollusks, or where the palæontological or the embryological terms of comparison are wanting or very imperfect.

Beginning with the palæontological history of the regular Sea-urchins of the time of the Trias, when they constituted an unimportant group as compared with the Crinoids, we find the Echini of that time limited to representatives of two families. One of these, the genus Cidaris, has continued to exist, with slight modifications, up to the present time, and not less than one tenth of all the known species of fossil Echini belong to this important genus, which in our tropical seas is still a prominent one. It is interesting here to note that in the Cidaridæ the modifications of the test are not striking, and the fossil genera appearing in the successive formations are distinguished by characters which often leave us in doubt as to the genus to which many species should be referred. In the genus Rhabdocidaris, which appears in the lower Jura, and which is mainly characterized by the extraordinary development of the radioles, we find the extreme of the variations of the spines in this family. From that time to the present day the most striking 
differences have existed in the shape of the spines, not only of closely allied genera, but even in specimens of the same species-differences which in some of the species of to-day are as great as in older geological periods. The oldest Cidaridæ are remarkable for their narrow poriferous zones. It is only in the Jura that they widen somewhat; subsequently the pores become conjugated, and only later, during the Cretaceous period, do we find the first traces of any ornamentation of the test (Temnocidaris) so marked at the present day in the genus Goniocidaris. So far, then, as the Cidaridx are concerned, the modifications which take place from their earliest appearance are restricted to slight changes in the poriferous zone and in the ornamentation of the test, accompanied with great variability in the shape of the primary radioles. We must except from this statement the genera Diplocidaris and Tetracidaris, to which I shall refer again. The representatives of the other Triassic family become extinct in the lower Tertiaries. The oldest genus (Hemicidaris) undoubtedly represents the earliest deviations from the true Cidaris type-modifications which affect not only the poriferous zone, but the test, the actinal and the abactinal systems, while, from the extent of these minor changes, we can trace out the gradual development of some of the characteristics in families of the regular Echini now living. The genus Hemicidaris may be considered a Cidaris in which the poriferous zone is narrow and undulating, in which the granules of the ambulacral system have become minute tubercles in the upper portion of the zone and small primary tubercles in its actinal region, in which many of the interambulacral granules become small secondaries, in which the plates of the actinal system have become reduced in number and the apical system has become a narrow ring, and finally in which the primary radioles no longer assume the fantastic shapes so common among the Cidaridæ.

We can trace in this genus the origin of the modifications of the poriferous zone, leading us, on the one side, through genera with merely undulating lines of pores to more or less distinct confluent arcs of pores formed round the primary ambulacral tubercles, and, on the other, to the formation of open arcs of three or more pairs of pores. The first type culminates at the present day with the Arbaciadæ, the other with the Diadematidæ, Triplechinidæ, and Echinometradæ. This specialization very early takes place, for already in the lower Jura Stomechinus has assumed the principal characteristics of the Triplechinidæ of to-day. 
Although in Hemicidaris the number of the coronal plates has increased as compared with the Cidaridæ, and while we find that in many genera, even of those of the present day, the number of the coronal plates is still comparatively small, yet, as a general rule, the more recent formations contain genera in which the increase in number of the interambulacral plates is accompanied by a corresponding decrease in the number of plates of the interambulacral area, so characteristic thus far of the Cidaridæ and Hemicidaridæ, a change also affecting the size of the primary ambulacral tubercles. This increase in the number of the coronal plates is likewise accompanied by the development of irregular secondary and miliary tubercles, and the disappearance in this group of the granular tuberculation, so important a character in the Cidaridæ. With the increase in the number of the interambulacral coronal plates, the Pseudodiadematidæ still retain prominent primary tubercles, recalling the earlier Hemicidaride and Cidaridæ, and, as in the Cidaridæ proper, the test is frequently ornamented by deep pits or by ridges formed by the junction of adjoining tubercles. The genital ring becomes narrower, aud the tendency to the specialization of one of its plates, the madreporite, more and more marked.

With the appearance of Stomechinus, the Echinidæ proper already assume in the Jura the open arcs of pores, the large number of coronal interambulacral plates, the specialization of the secondary tubercles, and the large number of primary tubercles in each plate. With the appearance of Sphorechinus in the early Tertiary come in all the elements for the greater multiplication of the pairs of pores in the arcs of the poriferous zones, while the gigantic primary spines of some of the genera (Heterocentrotus) and the small number of primary tubercles are structural features which had completely disappeared in the group preceding the Echinometrades, to which they appear most closely allied.

Going back again to the Hemicidarida, it requires but slight changes to pass from them to Acrosalenia and to the Salenioe proper ; the latter have continued to the present day, and have, like the Cidaridæ, retained almost unchanged the characters of the genera which preceded them, combined, however, with a few Cidaridian and Echinid features which date back to the Triassic period. We can thus trace the modifications which have taken place in the poriferous zone, the apical and actinal systems, the coronal plates, the ambulacral and interambulacral tubercles, as well as in the radioles, and, in the most direct manner possible, indicate the origin of the peculiar combination of structural features which we find 
at any geological horizon. On taking in succession the modifications undergone by the different parts of the test, we can trace each one singly, without the endless complication of combinations which any attempt to trace the whole of any special generic combination would imply.

Leaving out of the question for the moment the Palæchinidæ, we find no difficulty in tracing the history of the characters of the genera of the regular Echini which have existed from the time of the Trias and are now living, provided we take up each character independently. Nothing can be more direct than the gradual modification of the simple, barely undulating poriferous zone, made up of numerous ambulacral plates covered by granules, such as we find it among the Cidaridæ of the Trias, first into the slightly undulating poriferous zone of the Hemicidaridæ, next into the indistinct arcs of pores of the Pseudodiadematidæ, then into the arcs with a limited number of pores of the Triplechinidæ, and finally to the polyporous arcs of the Echinometradæ. What can be more direct than the gradual modification to be traced in the development of the primary ambulacral tubercles, such as are characteristic of the Echinidæ of the present day, from their first appearance at the oral extremity of the ambulacral system of the Hemicidaridæ, and the increase in the number of primary interambulacral tubercles, accompanied by the growth of secondaries and miliaries, which we can trace in Hemicidaris, Acrosalenia, and Stomechinus, the increase in number of primary and secondary tubercles being accompanied by a reduction in the size of the radioles and a greater uniformity in their size and shape?

But while these modifications take place, the original structural feature may be retained in an allied group. Thus the Cidaridæ retain unchanged from the earliest time to the present day the few primary tubercles, the secondary granules, the simple poriferous zone, the imbricating actinal system, and the few coronal plates, with the large apical system and many-shaped radioles; while in the Salenidre the primary interambulacral tubercles, the secondary granules, the radioles, the genital ring are recognized features of the Cidaridæ, associated, however, with an Echinid actinal and anal system, Hemicidarid primary ambulacral tubercles, and an Echinid poriferous zone. In the same way, in the Diadematidx, the large primary interambulacral tubercles are Cidaridian features, while the structure of the ambulacral tubercles is Hemicidaridian. The existence of two kinds of spines is another Cidaridian feature, while the apical and actinal systems have become modified in the same direction as that 
of the Echinidæ. The more recent the genus, the greater is the difficulty of tracing in a direct manner the origin of any one structural feature, owing to the difficulty of disassociating structural elements characteristic of genera which may be derived from totally different sources. This is particularly the case with genera having a great geological age. Many of them, especially among the Spatangoids, show affinities with genera following them in time, to be explained at present only on the supposition that, when a structural feature has once made its appearance, it may reappear subsequently, apparently as a new creation, while, in reality, it is only its peculiar combination with structural features with which it had not before been associated (a new genus) which conceals in that instance the fact of its previous existence. A careful analysis, not only of the genera of the order, but sometimes of other orders which have preceded this combination in time, may often reveal the elements from which have been produced apparently unintelligible modifications.

There is, however, not one of the simple structural features in the few types of the Triassic and Liassic Echini from which we can so easily trace the origin of the structural features of all the subsequent Echinid genera, which is not also itself continued to the present day in some generic type of the present epoch, fully as well characterized as it was at the beginning. In fact, the very existence to-day of these early structural features seems to be as positive a proof of the unbroken systematic affinity between the Echini of our seas and those of the Trias, as the uninterrupted existence of the genus Pygaster or Cidaris from the Trias down to the present epoch, or as the connexion of many of the genera of the Chalk with those of our epoch (Salenia, Cyphosoma, Psammechinus, \&c.).

Passing to the Clypeastridæ, we find there, as among the Desmosticha, that the earliest type, Pygaster, has existed from the Trias to the present time, and that while we can readily reconstruct, on embryological grounds, the modifications the earliest Desmosticha-like Echini should undergo in order to assume the structural features of Pygaster, yet the early periods in which the precursors of the Echinoconidæ and Clypeastridx are found have thus far not produced the genera in which these modifications actually take place. But, starting from Pygaster, we naturally pass to Holectypus, to Discoidea, to Conoclypus, on the one side; while, on the other, from Holectypus to Echinocyamus, Sisnondia, Fibularia, and Mortonia we have the natural sequence of the characters of the existing Echinanthidæ, Laganidæ, and Scutellidæ, the 
greater number of which are characteristic of the present epoch. If we were to take in turn the changes undergone in the arrangement of the plates of the test, as we pass from Pygaster to Holectypus, to Echinocyamus, and Echinanthidæ, we should have in the genera which follow each other in the palæontological record an unbroken series showing exactly what these modifications have been. In the same way the modifications of the abactinal and anal systems, and those of the poriferous zone, can equally well be followed to Echinocyamus, and thence to the Clypeastridæ; while a similar sequence in the modifications of these structural features can be followed from Mortonia to the Scutellidæ of the present period.

Passing finally to the Petalosticha we find no difficulty in tracing theoretically the modifications which our early Echinoconidæ of the Lias should primarily undergo previous to the appearance of Galeropygus. The similarity of the early Cassiduloid and Echinoneoid types points to the same systematic affinity, and perhaps even to a direct and not very distant relationship with the Palæchinidæ. For if we analyze the Echinothurioe of the present day we find in genera like Phormosoma many structural features, such as the shape of the test, the character of the spines, the structure of the apical system, that of the poriferous zone, indicative of possible modifications in the direction of Pygaster or of Galeropygus, which have as yet not been taken into account.

Adopting for the Petalosticha the same method of tracing the modifications of single structural features in their palæontological succession, we trace the comparatively little modified palæontological history of the Echinoneidæ of the present day from the Pyrina of the lower Jura. This, in its turn, has been preceded by Hyboclypus and Galeropygus, while the Echinolampadx of the present day date back, with but trifling modifications, to the Echinobrissus of the Lias, itself preceded by Clypeus; and they have been subject only to slight generic changes since that time, Echinobrissus being still extant, while such closely allied genera as Catopygus and Cassidulus of the earlier Cretaceous are still represented at the present day-the modifications taking place in the actinal system, in the ambulacral zones of the Echinoconida and of the Echinolampadæ showing the closest possible systematic affinity in these families. Starting again from Hyboclypus, with its elongate apical system, we naturally pass to Collyrites and the strange Dysasteridæ, forms which, in their turn, are closely allied to the Holasterida. From Holaster on the one side, and from Toxaster on the other, we find an unbroken 
sequence of structural characters uniting the successive genera of Holasteridæ, such as Cardiaster, Offaster, Stenonia, Ananchytes, and Asterostoma, with Palceopneustes, Homolampas, and the Pourtalesioe of the present day, while from the genera of the Toxasteridæ we naturally pass to the Cretaceous Hemiaster; in this genus and the subsequent Micraster we find all the elements necessary for the modifications which appear in the Spatanginæ from the time of the Chalk to the present day. These modifications result in genera in which we trace the development of the fascioles, of the actinal, anal, and abactinal plastrons, of the beak, the formation of the petaloid ambulacra, first flush with the test, and little by little changed into marsupial pouches, the growth of the anterior groove and the manifold modifications of the ambulacral system in Spatangus, Agassizia, and Echinocardium, often recalling in some of its features structural characters of families which have preceded this in time.

Apparently in striking contrast with the Echini of the Secondary period and those which have succeeded them stand the Palrozoic Echini; but when we have examined the embryology of Echini, we shall be better prepared to understand the structure and the affinities of the Palæchinidæe with the Echini of the present day and their immediate predecessors.

Taking up now the embryological development of the several families which will form the basis of our comparisons, beginning with the Cidaridæ, we find that in the earliest stages they very soon assume the characters of the adult, the changes being limited to the development of the abactinal system, the increase in number of the coronal plates, and the modifications of the proportionally gigantic primary radioles.

In the Diadematidæ the changes undergone by the young are limited to the gradual transformation of the embryonic spines into those which characterize the family, to the changes of the vertical row of pores in the ambulacral area into ares of three or four pairs of pores, and to the specialization of the actinal and abactinal systems.

In the Arbaciadæ the young stages are remarkable for the prominent sculpture of the test, for the flattened spines, for their simple poriferous zone, for their actinal system, and for their genital ring. The anal plates appear before the genital ring.

In the Echinometradæ the young thus far observed are characterized by the small number of their primary tubercles, the large size of the spines, the simple vertical row of pores, the closing of the anal ring by a single plate, and the turban- 
shaped outline of the test. Little by little the test loses with increasing age this Cidaris-like character ; it reminds us, from the increase in the number of its plates, more of Hemicidaris, then, with their still greater increase, of the Pseudodiadematidæ, and, finally, of the Echinometradæ proper. The spines, following pari passu the changes of the test, lose little by little their fantastic embryonic or, rather, Cidaris-like appearance, and become more solid and shorter, till they finally assume the delicately fluted structure characteristic of the Echinometradæ. The vertical poriferous zone is first changed into a series of connected vertical arcs, which become disjointed, and form, with increasing age, the independent ares of pores, composed of three or more pair of pores, of the Echinometradæ.

In the Echinidæ proper we find in the young stages the same unbroken vertical line of pores, which gradually becomes changed to the characteristic generic types. We find, as in the Echinometradæ, an anal system closed with a single plate, and an abactinal system separating in somewhat more advanced stages from the coronal plates of the test. This is as yet made up of a comparatively small number of plates, carrying but few large primary tubercles, with fantastically shaped spines entirely out of proportion to the test, but which, little by little, with the increase of the number of coronal plates, the addition of primary tubercles, and their proportional decrease in size, assume more and more the structure of the genus to which the young belongs. The original anal plate is gradually lost sight of from the increase in number of the plates covering the anal system, and it is only among the Temnopleuridæ that this anal plate remains more or less prominent in the adult. In the Salenidæ, of which we know as yet nothing of the development, this embryonic plate remains permanently a prominent structural feature of the apical system*.

Among the Clypeastroids the changes of form they undergo during growth are most instructive. We have in the young Fibularinæ an ovoid test, a small number of coronal plates surmounted by few and large primary tubercles, supporting proportionally equally large primary radioles, simple rectilinear poriferous zones, no petaloid ambulacra-in fact scarcely one of the features we are accustomed to associate with the

* The young of the following genera have served as a basis for the preceding analysis of the embryonic stages of the Desmosticha:-Cidaris, Dorocidaris, Goniocidaris, Arbacia, Porocidaris, Strongylocentrotus, Echinometra, Echinus, Toxopneustes, Hipponoë, Temnopleurus, Temnechinus, and Trigonocidaris. 
Clypeastroids is as yet prominently developed. But rapidly, with increasing size, the number of primary tubercles increases, the spines lose their disproportionate size, the pores of the abactinal region become crowded and elongate, and a rudimentary petal is formed. The test becomes more flattened, the coronal plates increase in number, and it would be impossible to recognize in the young Echinocyamus, for instance, the adult of the Cidaris-like or Echinometra-like stages of the Sea-urchin, had we not traced them step by step. Most interesting also is it to follow the migrations of the anal system, which, to a certain extent, may be said to retain the embryonic features of the earlier stages of all Echinoderm embryos, in being placed in more or less close proximity to the actinostome. What has taken place in the growth of the young Echinocyamus is practically repeated for all the families of Clypeastroids: a young Echinarachnius, or Mellita, or Encope, or a Clypeaster proper resembles at first more an Echinometra than a Clypeastroid; they all have simple poriferous zones and spires and tubercles out of all proportion to the size of the test *.

When we come to the development of the Spatangoids we find their younger stages also differing greatly from the adult. Among the Nucleolidæ, for instance, the young stages have as yet no petals, but only simple rectilinear poriferous zones. They are elliptical with a high test, with a single large primary tubercle for each plate, and a simple elliptical actinostome, withont any trace of the typical bourrelets and phyllodes so characteristic of this family. Very early, however, this condition of things is changed, the test soon becomes more flattened, the petals begin to form as they do in the Clypeastroids, and we can soon trace the rudiments of the peculiar bourrelets characteristic of the family, accompanied by a rapid increase in the number of tubercles and in that of the coronal plates.

Among the Spatangidæ some are remarkable in their adult condition for their labiate actinostome, for the great development of the petals, for the presence of fascioles surrounding certain definite areas, for the small size of the tubercles, the general uniformity in the spines of the test, and the specialization of their anterior and posterior regions. On examining the young stages of this group of Spatangoids, not one of these structural features is as yet developed. The actinostome is simple, the poriferous zone has the same simple

* Among the Clypeastroids I have examined the young of Echinocyamus, Fibularia, Mellita, Laganum, Echinarachnius, Encope, Clypeaster, and Echinunthus. 
structure from the actinostome to the apex, the primary tubercles are large, few in number, surrounded by spines which would more readily pass as the spines of Cidaridæ than of Spatangoids. The fascioles are either very indistinctly indicated, or else the special lines have not as yet made their appearance; the ambulacral suckers of the anterior zone are as large and prominent as those of the young stages of auy of the regular Echini. It is only little by little, with advancing age, that we begin to see signs of the specialization of the anterior and posterior parts of the test, that we find the characteristic anal or lateral fascioles making their appearance; only with increasing size that the spines lose their Cidaris-like appearance, that the petals begin to be formed, and that the simple actinostome develops a prominent posterior lip. In the genus Hemiaster the young stages are especially interesting, as long before the appearance of the petals, while the poriferous zone is still simple, the total separation of the bivium and of the trivium of the ambulacral system, so characteristic of the earliest Spatangoids (the Dysasteridæ), is very apparent*.

From this rapid sketch of the changes of growth in the principal families of the recent Echini we can now indicate the transformations of a more general character through which the groups as a whole pass.

In the first place, while still in the Pluteus stage all the young Echini are remarkable for the small number of coronal plates, and for the absence of any separation between the actinal and abactinal systems and the test proper. They all further agree in the large size of the primary spines of the test, whether it be the young of a Cidaris, an Arbacia, an Echinus, a Clypeaster, or a Spatangoid. They all in their youngest stages have simple vertical ambulacral zones; beyond this we find, as changes characteristic of some of the Desmosticha, the specialization of the actinal system from the coronal plates, the formation of an anal system, the rapid increase in the number of coronal plates, with a corresponding increase in the number of the spines and a proportional reduction of their size, the formation of an abactinal ring, and the change of the simple vertical poriferous zone into one composed of independent arcs.

In the Spatangoids and Clypeastroids we find common to both groups the shifting of the anal system to its definite place, the modifications of the abactinal part of the simple

* For this sketeh of the embryology of the Petalosticha I have examined the young of Echinolampas, Echinoneus, Echinocardium, Brissopsis, Agassizia, Spatangus, Brissus, and Heniaster. 
ambulacral system in order to become petaloid, and the gradual change of the elliptical ovoid test of the young to the characteristic generic test, accompanied by the rapid increase in the number of the primary tubercles and spines. Finally, limited to the Spatangoids are the changes they undergo in the transformation of the simple actinostome to a labiate one, the specialization of the anterior and posterior parts of the test, and the definite formation of the fascioles.

Comparing this embryonic development with the palæontological one, we find a remarkable similarity in both, and in a general way there seems to be a parallelism in the appearance of the fossil genera and the successive stages of the development of the Echini as we have traced it.

We find that the earlier regular Echini all have more or less a Cidaris-like look (that is, they are Echini with few coronal plates, large primary tubercles with radioles of a corresponding size), that it is only somewhat later that the Diademopsidæ make their appearance, which, in their turn, correspond within certain limits to the modifications we have traced in the growth of the young Diadematidæ and Arbaciadæ. The separation of the actinal system from the coronal plates has been effected. The poriferous zone has either become undulating or forms somewhat indefinite open arcs; we find in all the genera of this group a larger number of coronal plates, more numerous primaries, the granules of the Cidaridæ replaced by secondaries and miliaries, and traces of a Hemicidaris-like stage in the size of the actinal ambulacral tubercles.

Comparing in the same way the palæontological development of the Echinidæ proper, we find that, on the whole, they agree well with the changes of growth we can still follow to-day in their representatives, and that, as we approach nearer the present epoch, the fossil genera more and more assume the structural features which we find developed last among the Echinidæ of the present day. Very much in the same manner as a young Echinus develops, they lose, little by little, first their Cidaridian affinities, which become more and more indefinite; next their Diadematidian affinities, if I may so call the young stages to which they are most closely allied; and finally, with the increase in the number of the coronal plates, the great numerical development of the primary tubercles and spines, and that of the secondaries and miliaries which we can trace in the fossil Echini of the Tertiaries, we pass insensibly into the generic types characteristic of the present day.

Ann. \&Mag. N. Hist. Ser. 5. Vol. vi. 
Although we know nothing of the embryology of the Salenidæ, yet, like the Cidaridæ, they have in a great measure remained a persistent type, the modifications of the group being all in the same direction as those noticed in the other Desmosticha-a greater number of coronal plates, the development of secondaries and miliaries, combined with a specialization of the actinal system not found in the Cidaridæ.

An examination of the succession of the Echinoconidr shows but little modification from the earliest types; the changes, however, are similar to those undergone by the Clypeastroids and Petalosticha, though they do not extend to modifications of the poriferous zone, but are mainly changes in the actinostome and in the tuberculation. In fact, the group of Echinoconidæ seems to hold somewhat the same relation to the Clypeastroids which the Salenidx hold to the Cidaridæ; and the earliest genus of the group (Pygaster) has remained, like Cidaris, a persistent type to the present day.

The earliest Clypeastroids are all forms which resemble the Fibularinæ and the genera following Echinocyamus and Fibularia; they are mainly characterized by the same changes which an Echinarachnius or a Mellita, for instance, undergoes as it passes from its Echinocyamus stage to the Laganum or Encope stage. The comparison is somewhat more complicated when we come to the Spatangoids. The comparison of the succession of genera in the different families, as traced in the Desmosticha and Clypeastroids, is made difficult from the persistency of the types preceding the Echinoneidæ and the Ananchytidæ, which have remained without important modifications from the time of the Lower Cretaceous; previous to that time the modifications of the Cassidulidx are found to agree with the changes which have been observed in the growth of Echinolampas. The early genera, like Pygurus, have many of the characteristics of the test of the young Echinolampas. The development of prominent bourrelets and of the floscelle and petals goes on side by side with that of genera in which the modification of the actinostome, of the test, and of the petals is far less rapid, one group retaining the Echinoneus features, the other culminating in the Echinolampas of the present day, and having likewise a persistent type, Echinobrissus, which has remained with its main structural features unchanged from the Jura to the present day. That is, we find genera of the Cassidulidæ which recall the early Echinoneus stage of Echinolampas, next the Caratomus stage, after which the floscelle, bourrelets, and petals 
of the group become more prominent features of the suceeding genera. Accompanying the persistent type Echinobrissus, genera appear in which either the bourrelets or petals have undergone modifications more extensive than those of the same parts in the genera of the Echinoneus or Caratomus type.

The earliest Spatangoids belong to the Dysasteridæ, apparently an aberrant group, but which, from the history of the young Hemiaster, we now know to be a strictly embryonic type, which, while it thus has affinities with the true Spatangoids, still retains features of the Cassidulide in the mode of development of the actinostome and of the petals, as well as of the anal system. The genera following this group, Holaster and Toxaster, can be well compared, the one to the young stages of Spatangus proper before the appearance of the petals, when the ambulacra are flush with the test, and when the test is more or less ovoid, the other to a somewhat more advanced stage, when the petals have made their appearance as semipetals. In both cases the actinostome has the simple structure characteristic of all the young Spatangoids. The changes we notice in the genera which follow them lead in the one case through very slight modifications of the abactinal system, of the anterior and posterior extremities of the test, to the Ananchytid-like Spatangoids of the present day, the Pourtalesioe, the genus Holaster itself persisting till well into the middle of the Tertiary period; while, on the other side, we readily recognize in the Spatanginæ which follow Toxaster (a persistent type which has continued as Palcostoma to the present day) the genera which correspond to the young stages of such Spatangoids as Spatangus and Brissopsis of the present day-genera which, on the one hand, lead from Hemiaster (itself still represented in the present epoch), through stages such as Cyclaster, Peripneustes, Brissus, and Schizaster, and, on the other, through Micraster and the like, to the Spatangoids, in which the development of the anal plastron and fasciole performs an important part, while in the former group the development of the peripetalous fasciole and of the lateral fasciole can be followed. None of the genera of Petalosticha belonging to the other groups develops any fasciole in the sense of circumscribing a limited area of the test.

The comparison of the genera of Echini which have appeared since the Lias with the young stages of growth of the principal families of Echini, shows a most striking coincidence, amounting almost to identity, between the successive fossil genera and the various stages of growth. This identity cannot, however, be traced exactly. in the way in which it 26 * 
has usually been understood, while there undoubtedly exists in the genera which have appeared one after the other a gradual increase in certain families in the number of forms, and a constant approach in each succeeding formation, in the structure of the genera, to those of the present day. It is only in the accordance between some special points of structure of these genera and the young stages of the Echini of the present day that we can trace an agreement, which becomes more and more limited as we go further back in time. We are either compelled to seek for the origin of many structural features in types of which we have no record, or else we must attempt to find them existing potentially in groups where we had as yet not succeeded in tracing them. The parallelism we have traced does not extend to the structure as a whole. What we find is the appearance among the fossil genera of certain structural features giving to the particular stages we are comparing their characteristic aspect. Thus, in the succession of the fossil genera, when a structural feature has once made its appearance, it may either remain as a persistent structure, or it may become gradually modified in the succeeding genera of the same family, or it may appear in another family associated with other more marked structural features which completely overshadow it. Take, for instance, among the Desmosticha, the modifications of the poriferous zone of the actinal and abactinal systems of the coronal plates, of the ambulacral and interambulacral systems, the changes in the relative proportion of the primary tubercles, and the development of the secondaries. These are all structural features which are modified independently one of the other; we may find simultaneous development of these features in parallel lines, but a very different degree of development of any special feature in separate families.

This is as plainly shown in the embryological as in the palæontological development. In the Cidaridæ there is the minimum of specialization in these structural features. In the Diademopsidæ there is a greater range in the diversity of the structure of the poriferous zone and of the coronal plates, as well as of the actinal system. There is a still greater range among the Echinidæ; while among the Salenidæ the modifications, as compared with those of the Echinidæ and Diademopsidæ, are somewhat limited again, being restricted as far as relates to the poriferous zone and coronal plates, but specialized as far as the actinal system is concerned, and specially important with reference to the structure of the apical system. The special lines in which these modifications take place produce, of course, all possible combinations; yet they give us the key 
to the sudden appearance, as it were, of structural features of which the relationship must be sought in very distantly related groups. It is to this specialty in the palæontological development that we must trace, for instance, the Cidarid affinities of the Salenioe, their papillæ, the existence of a few large primary interambulacral tubercles, the structure of their apical system, and their large genital plates; while it is to their affinities with the Hemicidaridæ that we must refer the presence of the few larger primary ambulacral tubercles at the base of the ambulacral area, and by their Diademopsid and Echinidian affinities that we explain the indented imbricated actinal system with the presence of a few genuine miliaries. But all the structural features which characterize the earliest types of the Desmosticha can in reality be traced, only in a somewhat rudimentary form, even in the Cidaridæ. The slight undulation of the closely packed, nearly vertical poriferous zone is the forerunner of the poriferous zone first separated into vertical ares and then into independent arcs. The limitation in the number of the rows of granules in the ambulacral zone, and their increase in size, are the first traces of the appearance of the somewhat larger primary ambulacral tubercles of the Hemicidaridæ and Salenioe. The existence of the smooth cylindrical spines of the abactinal region of the test naturally leads to similar spines covering the whole test in the other families of the Desmosticha. The difference existing in the plates covering the actinal system from those of the coronal plates leads to the great distinction between the structure of the actinal system and of the coronal plates in some of the Echinidæ.

Passing to the Clypeastrida and Petalosticha, we trace a parallelism of the same kind, and readily in the successive genera of fossil Clypeastroids, but often in widely separated genera-the precise modifications which the poriferous zone has undergone as it first becomes known to us in Echinocyamus and Fibularia, and as we find it in the most complicated petaloid stage of the Clypeastroids of the present day. We readily trace the changes the test undergoes from its comparatively ovoid and swollen shape, to assume first that of the less gibbous forms, next that of the Laganida, and finally of the flat Scutellidæ; while we trace in the Echinanthidæ the persistent structural features of some of the earliest Clypeastroids, together with an excessive modification of the poriferous zone. Likewise for the Echinoconidæ we trace mainly the slight modifications of the poriferous zone and of the coronal plates; and, finally, when we come to the Spatangidæ we find no difficulty in tracing from the most Desmostichoid of the Spatangoid genera the modifications of a test 
in which the ambulacral and interambulacral areas are made up of plates of nearly uniform size, in which the anterior and posterior extremities are barely specialized, to the most typical of the Ananchytidæ, in which the anterior and posterior extremities have developed the most opposite and extraordinary structural features. In a similar way we can trace among the fossil genera of different families the gradual development of the actinal plastron from its very earliest appearance as a modification of the posterior interambulacral area of the actinal side, or the growth of the posterior beak into an anal snout, the successive changes of the anal groove, the formation of the actinal labium, or the development of the bourrelets and phyllodes from a simple circular actinostome, the gradual deepening of the slight anterior groove of some early Spatangoid to form the deeply sunken actinal groove. Equally well we can trace the modifications of the ambulacral system as it passes from the simple poriferous zones of the earlier Spatangoids to genera in which the petaliferous portion makes its appearance, and finally becomes the specialized structure of our recent Spatangoid genera, such as Sichizaster, Moira, and the like. Finally, we can trace, to a certain extent, the development of the fascioles, on one side, from genera like Hemiaster, in which the peripetalous fasciole is prominent, to genera like Brissopsis, Brissus, and the like, of the present day; on the other, perhaps, or in both combined, the formation of a lateral and anal fasciole from genera like Micraster in Spatangus and Agassizia. Thus we must, on the same theory of the independent modifications of special structural features, trace the many and complicated affinities which so constantly strike us in making comparative studies, and which render it impossible for us to express the manifold affinities we notice without taking up separately each special structure. Any attempt to take up a combination of characters, or a system of combinations, is sure to lead us to indefinite problems far beyond our power to grasp.

In the oldest fossil Clypeastroids and Petalosticha, as well as in the Desmosticha, we also find the potential expression of the greater number of the modifications subsequently carried out in genera of later date. The semipetaloid structure of some of the earlier genera of Spatangoids, the slight modifications of some of the plates of the actinal side near the actinostome, are the precursors, the one of the highly complicated petaloid ambulacra of the recent Spantangoids, the other of the actinal plastron, leading as it does also to the important differences subsequently developed in the anterior and posterior extremities of the test, as well as to the modifications which lead to the existence of a highly labiate actinostome. 
The appearance of a few miliaries near the actinostome constitutes the first rudimentary bourrelets.

Groing back now to the Palæchinidæ, the earliest representatives of the Echini in Palæozoic times, without any attempt to trace the descent of any special type from them, we may, perhaps, find some clue to the probable modifications of their principal structural features preparatory to their gradual disappearance. In the structure of the coronal plates, the specialization of the actinal and abactinal systems, the conditions of the ambulacral system, we must compare them to stages in the embryonic development of our recent Echini with which we find no analogues in the fossil Echini of the Lias and the subsequent formations. In order to make our parallelism we must go back to a stage in the embryonic history of the young Echini, in which the distinction to be made between the ambulacral and interambulacral systems is very indefinite, in which the apical system is, it is true, specialized, but in which the actinal system remains practically a part of the coronal system. But here the comparison ceases, and, although we can trace in the palæontological development of such types as Archoocidaris or Bothriocidaris nodifications which would lead us, without great difficulty, on the one side to the Cidaridæ, and on the other to the Echinothurice and Diadematidæ of the present day, we cannot fail to see most definite indications in some of the structural features of the Palæchinidæ of characteristics which we have been accustomed to associate with higher groups. The minute tuberculation, for instance, of the Clypeastroids and Spatangoids, already existing in the Melonitidæ, the genital ring, and anal system, are quite as much Echinid as Cidarid. The polyporous genera of the group represent, to a certain extent, the Polypori of the regular Echini; and the lapping of the actinal plates of the Cidaridæ and of the coronal plates in some of the Diadematidæ, as well as the existence of such genera as Tetracidaris, of four interambulacral plates in Astropyga, and of a large number of ambulacral plates in some of the recent Echinometradæ-all these are Palæchinid characters which we can explain on the theory of the independent development of the structural features of which they are modifications. We should, however, remember that the existence of a large number of coronal plates, especially interambulacral plates, in the Palæchinidæ is a mere vegetative character which they hold in common with all the Crinoids, a character which is reduced to a minimum among the Holothurians, and still persists in full force among the Pentacrini of the present day, as well as the Astrophytidæ and Echinidæ. 
It would lead me too far to institute the same comparison between the embryonic stages of the different orders of Echinoderms and their earliest fossil representatives. We may, however, in a very general way, state that we know the earliest embryonic stages of the orders of Echinoderms of today, which, with the exception of the Blastoidea and Cystideans, are identical with the fossil orders, and that, so far as we know, they all begin at a stage where it would be impossible to distinguish a Sea-urchin from a Starfish, or an Ophiuran, or a Crinoid, or an Holothurian-a stage in which the test, calyx, abactinal, and ambulacral systems are reduced to a minimum. From this identical origin there is developed at the present day, in a comparatively short period of time, either a Starfish, a Sea-urchin, or a Crinoid; and if we have been able successfully to compare, in the development of typical structures, the embryonic stages of the young Echini with their development in the fossil genera, we may fairly assume that the same process is applicable when instituting the comparison within the different limits of the orders, but with the same restrictions: that is, if we wish to form some idea of the probable course of transformations which the earliest Echinoderms have undergone to lead us to those of the present day, we are justified in seeking for our earliest representatives of the orders such Echinoderms as resemble the early stages of our embryos, and in following, for them as for the Echini, the modifications of typical structures. These we shall have every reason to expect to find repeated in the fossils of later periods; and going back a step further we may, perhaps, get an indefinite glimpse of that first Echinodermal stage which should combine the structural features common to all the earliest stages of Echinoderm embryos.

And yet, among the fossil Echinoderms of the oldest periods, we have not as yet discovered the earliest type from which we would derive either the Starfishes, Ophiurans, Seaurchins, or Holothurians. With the exception of the latter, which we can leave out of the question at present, we find all the orders of Echinoderms appearing at the same time. But while this is the case, one of the groups attained in those earliest days a prominence which it gradually loses with the corresponding development of the Starfishes, Ophiurans, and Sea-urchins; it has steadily declined in importance: it is a type of Crinoids, the Cystideans, which culminated during Palæozoic times, and completely disappeared long before the present day. If we compare the early types of Cystideans with the typical embryonic Echinodermal type of the present day, 
we find they have a general resemblance, and that the Cystideans and Blastoids represent among the fossil Echinoderms the nearest approach we have yet discovered to this imaginary prototype of Echinoderms.

This may not seem a very satisfactory result to have attained. It certainly has been shown to be an impossibility to trace in the palæontological succession of the Echini any thing like a sequence of genera; no direct filiation can be shown to exist; and yet the very existence of persistent types, not only among the Echinoderms but in every group of marine animals, genera which have continued to exist without interruption from the earliest epochs at which they occur to the present day, would prove conclusively that at any rate some groups among the marine animals of the present day are the direct descendants of those of the earliest geological periods. When we come to types which have not continued so long but yet have extended through two or three great periods, we must likewise accord to their latest representatives a direct descent from the older. The very fact that the ocean basins date back to the earliest geological periods, and have afforded to the marine animals the conditions most favourable to an unbroken continuity under slightly varying circumstances, probably accounts for the great range in time during which many genera of Echini have existed. If we examine the interlacing in the succession of the genera characteristic of later geological epochs, we find it an impossibility to deny their continuity from the time of the Lias to the present day. The Cidaris of the Lias and the Rhabdocidaris of the Jura are the ancestors of the Cidaris of today. The Salenice of the Lower Chalk are those of the Salenioe of today. Acrosalenia extends from the Lias to the Lower Cretaceous, with a number of recent genera, which begin at the Eocene. The Pygaster of today dates back to the Lias; Echinocyamus and Fibularia commence with the Chalk. Pyrina extends from the Lower Jura through the Eocene. The Echinobrissus of today dates back to the Jura. Holaster lived from the Lower Chalk to the Miocene; and the Hemiaster of today cannot be distinguished from the Hemiaster of the Lower Cretaceous.

Such descent we can trace, and trace as confidently as we trace a part of the population of North America of today as the descendants of some portion of the population of the beginning of this century. But we can go no further with confidence, and bold indeed would he be who would attempt, even in a singie State, to trace the genealogy of the inhabitants from those of ten years before. We had better acknow- 
ledge our inability to go beyond a certain point; any thing beyond the general parallelism I have attempted to trace, which in no way invalidates the other proposition, we must recognize as hopeless.

But in spite of the limits which have been assigned to this general parallelism, it still remains an all-essential factor in elucidating the history of palæontological development; and its importance has but recently been fully appreciated. For, while the fossil remains may give us a strong presumptive evidence of the gradual passage of one type to another, we can only imagine this modification to take place by a process similar to that which brings about the modifications due to different stages of growth-the former taking place in what may practically be considered as infinite time when compared to the short life-history which has given us, as it were, a résumé of the palæontological development. We may well pause to reflect that in the two modes of development we find the same periods of rapid modifications occurring at certain stages of growth or of historic development, repeating in a different direction the same phases. Does it, then, pass the limits of analogy to assume that the changes we see taking place under our own eyes in a comparatively short space of time-changes which extend from stages representing, perhaps, the original type of the group to their most complicated structures - may, perhaps, in the larger field of palæontological development, not have required the infinite time we are in the habit of asking for them?

Palæontologists have not been slow in following out the suggestive track; and those who have been anatomists and embryologists besides have not only entered into most interesting speculations regarding the origin of certain groups, but they have carried on the process still further, and have given us genealogical trees where we may, in the twigs and branches and main limbs and trunk, trace the complete filiation of a group as we know it today, and as it must theoretically have existed at various times to its very beginning. While we cannot but admire the boldness and ingenuity of these speculations upon genetic connection so recklessly launched during the last fifteen years, we find that, with but few exceptions, there is little to recommend in reconstructions which shoot so wide of the facts as far as they are known, and seem so readily to ignore them. The moment we leave out of sight the actual succession of the fossils and the ascertainable facts of post-embryonic development, to reconstruct our genealogy, we are building in the air. Ordinarily the twigs of any genealogical tree have only a 
semblance of truth; they lead us to branchlets having but a slight trace of probability, to branches where the imagination plays an important part, to main limbs where it is finally allowed full play, in order to solve with the trunk, to the satisfaction of the writer at least, the riddle of the origin of the group. It seems hardly credible that a school which boasts for its very creed a belief in nothing which is not warranted by common sense should descend to such trifling.

The time for genealogical trees is past; its futility can, perhaps, best be shown by a simple calculation which will point out at a glance what these scientific arboriculturists are attempting. Let us take, for instance, the ten most characteristic features of Echini. The number of possible combinations which can be produced from them is so great that it would take no less than twenty years, at the rate of one new combination a minute for ten hours a day, to pass them in review. Remembering now that each one of these points of structure is itself undergoing constant modifications, we may get some idea of the nature of the problem we are attempting to solve when seeking to trace the genealogy as understood by the makers of genealogical trees. On the other hand, in spite of the millions of possible combinations which these ten characters may assume when affecting not simply a single combination, but all the combinations which might arise from their extending over several hundred species, we yet find that the combinations which actually exist (those which leave their traces as fossils) fall immensely short of the possible number. We have, as I have stated, not more than twentythree hundred species actually representing for the Echini the results of these endless combinations. Is it astonishing, therefore, that we should fail to discover the sequence of the genera, even if the genera, as is so often the case, represent, as it were, fixed embryonic stages of some Sea-urchin of the present day? In fact, does not the very history of the fossils themselves show that we cannot expect this? Each fossil species, during its development, must have passed through stages analogous to those gone through by the Echini of the present day. Each one of these stages at every moment represents one of the possible combinations; and those which are actually preserved correspond only to the particular period and the special combination which any Seaurchin has reached. These stages are the true missing links, which we can no more expect to find preserved than we can expect to find a record of the actual embryonic development of the species of the present day without direct observation at the time. The actual number of species in 
any one group must always fall far short of the possible number; and for this reason it is out of the question for us to attempt the solution of the problem of derivation, or to hope for any solution beyond one within the most indefinite limits of correctness. If, when we take one of the most limited of the groups of the animal kingdom, we find ourselves engaged in a hopeless task, what must be the prospect should we attack the problem of other classes or groups of the animal kingdom, where the species run into the thousands, while they number only tens in the case we have attempted to follow out? Shall we say "ignorabimus" or "impavidi progrediamus," and valiantly chase a phantom we can never hope to seize?

XLIV.-On a new Species of Gyracanthus, a Fossil Fish from the Coal-measures. By James W. DAvIS, F.G.S. \&c.

\section{Gyracanthus denticulatus, Davis (sp. n.).}

Spine: length 8.5 inches, greatest diameter (one third the length from the basal extremity) 7 of an inch. The spine is slightly curved, rather more so on the posterior than the anterior surface. The basal portion contracts slightly and has a rounded termination. The exposed part tapers gradually to a fine point. The spine is much compressed laterally; the anterior portion is rounded; and a deep cavity extends posteriorly from the base more than one third its length, and is continued internally to within a short distance from the point. The line dividing the exposed part of the spine from that which was enclosed in the body of the fish is very oblique; beginning 7 of an inch from the base in front, it extends across to the back, where it is 3 inches from the base. The basal portion has the usual fibrous character. The exposed surface is covered with the ridges and grooves characteristic of the genus Gyracanthus; they extend very obliquely from the posterior to the anterior surface, where they meet with the ridges from the opposite side at a sharp angle; they are continuous; but the surface of the ridge is produced at short intervals, so as to present a beaded or tuberculate appearance, especially towards the anterior surface. Extending from the point along the posterior portion of each side is a space which is free from the gyrating ridges and grooves. It is about $2 \frac{1}{2}$ inches long and $\cdot 15$ of an inch wide; with the exception of two or three minute ridges running parallel with 